Short Communication http://ajol.info/index.php/ijbcs http://indexmedicus.afro.who.int

\title{
Effect of ageing on some biophysical parameters amongst males in Benin City,
} Nigeria

\section{F.A. EHIAGHE}

Department of Hematology, College of Health Sciences, Igbinedion University, Okada, Nigeria. Lahor Research and Medical Centre, 121 Old Benin-Agbor Road, Benin City, Nigeria. Department of Medical Laboratory Sciences, Nnamdi Azikiwe University, Awka, Nigeria. E-mail :fredleo2547@yahoo.com

\begin{abstract}
This study was designed to assess the effect of ageing on the $\mathrm{CD}^{+} \mathrm{T}$ cells count, testosterone, progesterone, and estrogen concentration in a view to evaluating the alterations associated with it. A total of 102 subjects aged between 20 and 80 years participated in the study.CD4 ${ }^{+} \mathrm{T}$ cell was estimated using Partec cyflow counter. Testosterone, progesterone and estrogen were determined by enzyme-linked immunosorbent assay methods. Our finding revealed a significant decrease in absolute lymphocyte count, $\mathrm{CD} 4^{+} \mathrm{T}$ cells count, progesterone, and testosterone concentration of the elderly males when compared with the young males $(\mathrm{P}<$ 0.05). Ageing induces a decrease in $\mathrm{CD}^{+} \mathrm{T}$ cells, progesterone and testosterone level which could be linked to the complications associated it.

(C) 2015 International Formulae Group. All rights reserved.
\end{abstract}

Keywords: CD4+ T cells, ageing, testosterone, hypogonadism, thymus gland.

\section{INTRODUCTION}

It is well-established that ageing is associated with a decline in immune function (Gyubeck and Wick, 2002). A major contributing factor to impaired cellular immunity in the elderly is a decline in $\mathrm{T}$ cell repertoire diversity. Thymic involution with age results in the export of fewer naïve $T$ cells to the periphery. Decline in $\mathrm{CD}^{+} \mathrm{T}$ cell repertoire diversity has been clearly associated with impaired responses to new infections (Yager et al., 2008; Cian et al., 2010; Rudd et al., 2011). A major age-associated defect for $\mathrm{CD}^{+} \mathrm{T}$ cells has been shown to reduce Interleukin-2 production (Haynes and
Lefebvre, 2011). The higher incidence of infectious diseases (influenza), autoimmunity (rheumatoid arthritis), cancer (prostate) and cardiovascular diseases is an obvious issue in ageing (Pawelec, 2007). The most important contributor to the decline in immune function in the elderly is the changes observed in adaptive immunity (Goronzy and Weyand, 2005). Telomeric repeats (TTAGGG) shortening that is associated with ageing has been linked with increased DNA mismatch (Di-Mitri et al., 2011).

Testosterone deficiency is common as men grow older (Harman et al, 2001).Testosterone levels peak between ages 
20 and 40 years, and then decline gradually by approximately $1 \%$ per year. Lower testosterone levels is associated with frailty, reduced sexual activity, insulin resistance, cognitive decline, cardiovascular events and mortality in ageing males (Rudd et al., 2011). Does ageing in males have any effect on the $\mathrm{CD}^{+} \mathrm{T}$ cells and testosterone, progesterone and estrogen level? This study was designed to assess the effect of ageing on these biophysical parameters amongst males in Benin City, Nigeria with a view to evaluating the alteration associated with it.

\section{MATERIALS AND METHODS Subjects}

A total of 102 subjects aged between 20 and 80 years participated in the study. The participants were randomly recruited. Obese or underweight (BMI between 20 and 30 $\mathrm{kg} / \mathrm{m}^{3}$ ), smokers, alcoholics, diabetic, cardiac, renal, and respiratory disease patients were excluded. The participants gave informed consent. $6 \mathrm{ml}$ of venous blood was taken from the antecubital vein by venapunture. It was equally shared into an ethylene diamine tetra acetic acid container for absolute lymphocyte estimation and $\mathrm{CD}^{+} \mathrm{T}$ cell count. The other portion was added into an anticoagulant free container and allowed clot. It was subsequently centrifuge at $750 \mathrm{x} \mathrm{g}$ for 15 minutes to obtain serum. The serum was immediately aliquoted into an eppendorf tube place on ice and immediately stored at $-80{ }^{\circ} \mathrm{C}$ until testosterone, estrogen and progesterone were estimated.

\section{Absolute lymphocyte count estimation}

Absolute lymphocyte was determined using the sysmex automated Hematology analyzer as previously described by Ehiaghe et al. (2014).

\section{$\mathrm{CD4}^{+} \mathrm{T}$ cell count estimation}

$\mathrm{CD}^{+} \mathrm{T}$ cell count was estimated using Partec cyflow counter as described by Partec cyflow counter (2006).

\section{Serum testosterone estimation}

Serum testosterone was determined by enzyme linked immune sorbent assay technique. This test kit operates on the basis of competition between the conjugates and the testosterone in the sample(s) for a limited number of binding sites on the antibody coated wells. Twenty-five micro liters of standard or sample(s) was added per microplate.100 $\mu \mathrm{l}$ testosterone hormone conjugate was added to the standard or sample(s) and covered with a sealing tape. It was incubated at $37{ }^{\circ} \mathrm{C}$ for 1 hour. The solution was discarded and microplates washed three times with $300 \mu \mathrm{l}$ of $1 \mathrm{X}$ wash solution. $100 \mu \mathrm{l}$ of tetramethylbenzidine one step substrate was added to each well and incubated for 15 minutes at room temperature in the dark with gentle shaking. $100 \mu 1$ of stop solution was added to each microplate. The intensity of the color developed was measured at $450 \mathrm{~nm}$.

\section{Serum $17 \beta$ estradiol estimation}

Serum $17 \beta$ estradiol was determined by enzyme linked immune sorbent assay technique. This test kit operates on the basis of competition between the conjugates and the testosterone in the sample(s) for a limited number of binding sites on the antibody coated wells. Twenty five micro liters of standard or sample(s) was added per micro plate. $200 \mu \mathrm{l}$ hormone conjugate was added to the standard or sample(s) and covered with a sealing tape. It was incubated at $37^{\circ} \mathrm{C}$ for 2 hour. The solution was discarded and microplates washed three times with $300 \mu \mathrm{l}$ of $1 \mathrm{X}$ wash solution. $100 \mu \mathrm{l}$ of tetramethylbenzidine one step substrate was 
added to each well and incubated for 30 minutes at room temperature in the dark with gentle shaking. $100 \mu \mathrm{l}$ of stop solution was added to each microplate. The intensity of the color developed was measured at $450 \mathrm{~nm}$.

\section{Serum progesterone estimation}

Serum progesterone was determined by enzyme linked immune sorbent assay technique. This test kit operates on the basis of competition between the conjugates and the testosterone in the sample(s) for a limited number of binding sites on the antibody coated wells. Twenty micro liters of standard or sample(s) was added per micro plate. 200 $\mu 1$ hormone conjugate was added to the standard or sample(s) and covered with a sealing tape. It was incubated at $37^{\circ} \mathrm{C}$ for 1 hour. The solution was discarded and microplates washed three times with $300 \mu$ of $1 \mathrm{X}$ wash solution. $100 \mu \mathrm{l}$ of tetramethylbenzidine one step substrate was added to each well and incubated for 15 minutes at room temperature in the dark with gentle shaking.100 $\mu 1$ of stop solution was added to each microplate. The intensity of the color developed was measured at $450 \mathrm{~nm}$.

\section{Statistical analysis}

All numerical variables were expressed in mean $( \pm \mathrm{SD})$ and analyzed using oneway analysis of variance (ANOVA). Using
SPSS version 20.0, significant level was considered at $\mathrm{P}<0.05$.

\section{Ethics}

Ethical approval was obtained from the ethical committee of the Lahor Research Laboratories and Medical centre in Benin City, Edo State, Nigeria with reference number LRL/010/014.

\section{RESULTS}

Our findings revealed a significant decrease in absolute lymphocyte count, $\mathrm{CD} 4^{+}$ $\mathrm{T}$ cells, progesterone and testosterone concentration of the elderly males when compared with the young males $(\mathrm{P}<0.05)$ (Table 1). It also revealed a significant increase in estrogen level of the elderly males when compared with the young males $(\mathrm{P}<$ 0.05) (Table 1).

\section{DISCUSSION}

It is well-established that ageing is associated with a decline in immune function (Gyubeck and Wick, 2002). There is currently paucity published report on the effect of ageing on the immune system and the gonads of male subjects in Benin City, Nigeria, to the best of my knowledge, hence this study. The significant decrease in absolute lymphocyte count and $\mathrm{CD}^{+} \mathrm{T}$ cells count of the elderly as compared with the young males (Table 1).

Table 1: Comparison of mean $( \pm \mathrm{SD})$ of $\mathrm{CD}^{+} \mathrm{T}$ cell count (cells $\left./ \mu \mathrm{l}\right)$, estrogen $(\mathrm{pg} / \mathrm{ml})$, progesterone $(\mathrm{nmol} / \mathrm{l})$, testosterone $(\mathrm{ng} / \mathrm{ml})$ and absolute lymphocyte count (cells/ $\mu \mathrm{l})$ of elderly males and young males.

\begin{tabular}{llllll}
\hline Parameters & $\begin{array}{l}\text { CD4+T } \\
\text { cells count }\end{array}$ & Estrogen & Progesterone & Testosterone & $\begin{array}{l}\text { Absolute } \\
\text { lymphocyte count }\end{array}$ \\
\hline Elderly males $(\mathrm{n}=51)$ & $392 \pm 9.76$ & $95 \pm 1.34$ & $2.20 \pm 0.20$ & $3.17 \pm 0.2$ & $1.10 \pm 0.03$ \\
Young males $(\mathrm{n}=51)$ & $810 \pm 17.10$ & $41.1 \pm 1.90$ & $4.37 \pm 1.90$ & $4.12 \pm 0.2$ & $2.74 \pm 0.12$ \\
P- value & $<0.05$ & $<0.05$ & $<0.05$ & $<0.05$ & $<0.05$ \\
\hline \multicolumn{2}{c}{ P-value $<0.05$ was considered significant. }
\end{tabular}


These could be attributed to the shrinkage in the size and function of the thymus gland. This is in accordance with these findings. The shrinking in size and function of the thymus gland may leads to a reduction in the output of new naïve $\mathrm{T}$ cells toward the periphery (Hakim et al., 2005). $\mathrm{CD}^{+} \mathrm{T}$ cell pool in young individuals is mainly composed of naïve cells, the proportion of memory cells increases with ageing in both mice and humans (Kovaiou et al., 2005). The major age-associated defect for CD4 T cells has been shown to be a reduction in IL-2 production (Haynes and Lefebvre, 2011). The higher incidence of infectious diseases (influenza), autoimmunity (rheumatoid arthritis), cancer (prostate) and cardiovascular diseases is an obvious issue in ageing (Pawelec, 2007). The most important contributor to the decline in immune function in the elderly is the changes observed in adaptive immunity (Goronzy and Weyand, 2005). Telomeric repeats (TTAGGG) shortening that is associated with ageing has been linked with increased DNA mismatch (Di-Mitri et al., 2011).

A significant decrease in testosterone, progesterone and an increase the level of estrogen in elderly males as compared with the young males $(\mathrm{P}<0.05)$ (Table 1$)$. These could be linked to the reduction in the number of Leydig cells of the gonads. Mulligan et al., 2001 opined that the reduction in number of Leydig cells and the increased in the steroidogenic function of the aged gonads could be associated with an increase in the production of estrogen, and a rise in the levels of luteinizing hormone. It is reported that hypogonadism is associated with low testosterone levels, reduced sexual activity, insulin resistance, cognitive decline, cardiovascular events and mortality in ageing males (Yeap, 2009a; Yeap et al., 2012). Decreased testosterone levels are associated with increased risks of osteoporosis, metabolic syndrome and type 2 diabetes mellitus (Yeap, 2009b). Testosterone deficiency should be regarded as a risk factor for cardiovascular disease (Maggio and Basaria, 2009; Jones, 2010).

\section{Conclusion}

Ageing induces a decrease in $\mathrm{CD}^{+} \mathrm{T}$ cells count, progesterone and testosterone level. The elevated level of estrogen observed is possibly due to a feedback mechanism associated with hypogonadism. The molecular mechanism needs further investigation.

\section{REFERENCES}

Cicin-Sain L, Messaoudi I, Park B, Currier N, Planer S, Fischer M, Tackitt S, NikolichZugich D, Legasse A, Axthelm MK, Picker LJ, Mori M, Nikolich-Zugich J. 2007. Dramatic increase in naive $\mathrm{T}$ cell turnover is linked to loss of naive $\mathrm{T}$ cells from old primates. Proc Natl Acad Sci $U$ $S$ A, 104: 19960-19965.

Di Mitri D, Azevedo RI, Henson SM. 2011. Reversible senescence in human CD4+CD45RA+CD27-memory $\mathrm{T}$ cells. J. Immunol., 5: 2093-2100.

Ehiaghe FA, Agbonlahor DE, Ositadima MI, Ehiaghe IJ, Osadolor HB. 2014. Effect of academic stress on serum cortisol level and CD4 cell count in young male postgraduate students in Okada, Nigeria. Int. J. Biol. Chem. Sci., 8(3): 1249-1253.

Goronzy JJ, Weyand CM. 2005. T cell development and receptor diversity during ageing. Curr. Opin. Immunol., 17: 468-475.

Grubeck-Loebenstein B, Wick G. 2002. The aging of the immune system. $A d v$. Immunol., 80: 243-284.

Hakim FT, Memon SA, Cepeda R, Jones EC, Chow CK, KastenSportes C. 2005 Agedependent incidence, time course, and consequences of thymic renewal in adults. J. Clin. Invest., 115: 930-939.

Harman SM, Metter EJ, Tobin JD, Pearson J, Blackman MR. 2001. Longitudinal effects of aging on serum total and free testosterone levels in healthy men. Baltimore Longitudinal Study of Aging. J. Clin. Endocrinol. Metab., 86: 724-731. 
Haynes L, Lefebvre JS. 2011. Age-related Deficiencies in Antigen-Specific CD4 T cell Responses: Lessons from Mouse Models. Aging and dis., 2: 374-381.

Jones TH. 2010. Testosterone deficiency: a risk factor for cardiovascular disease? Trends in Endocrinology and Metabolism: TEM, 21: 496-503.

Kovaiou RD, Weiskirchner I, Keller M, Pfister G, Cioca DP, GrubeckLoebenstein B. 2005. Age-related differences in phenotype and function of CD4+ $\mathrm{T}$ cells are due to a phenotypic shift from naive to memory effector CD4+ T cells. Int. Immunol., 17: 13591366.

Maggio M, Basaria S. 2009. Welcoming low testosterone as a cardiovascular risk factor. International Journal of Impotence Research, 21: 261-264.

Mulligan T, Iranmanesh A, Veldhuis JD. 2001. Pulsatile iv infusion of recombinant human LH in leuprolide-suppressed men unmasksimpoverished Leydig-cell secretory responsiveness to midphysiological LH drive in the aging male. J. Clin. Endocrinol. Metab., 86: 5547-5553.

Partec Cyflow Counter (PCC). 2006. Typical steps of particle analysis using Partec cyflow counter. Instrument Operating Manual. Partec GmbH OHO-Hann-str 32, 0-48161: Munster, Germany; 5-8.

Pawelec G. 2007. Immunosenescence comes from age.Symposium on ageing research in immunology: The impact of genomics. EMBO Rep., 8: 220-223.

Rudd BD, Venturi V, Davenport MP, Nikolich-Zugich J. 2011. Evolution of the antigen-specific CD8+ TCR repertoire across the life span: evidence for clonal homogenization of the old TCR repertoire. J. Immunol., 186: 2056-2064.

Smithey MJ, Li G, Venturi V, Davenport MP, Nikolich-Zugich J. 2012. Lifelong persistent viral infection alters the naive $\mathrm{T}$ cell pool, impairing CD8 T cell immunity in late life. J. Immunol., 189: 53565366.

Yager EJ, Ahmed M, Lanzer K, Randall TD, Woodland DL, Blackman MA. 2008. Age-associated decline in $\mathrm{T}$ cell repertoire diversity leads to holes in the repertoire and impaired immunity to influenza virus. J. Exp Med., 205: 711723.

Yeap BB, Araujo AB, Wittert GA. 2012. Do low testosterone levels contribute to illhealth during male ageing? Critical Reviews in Clinical Laboratory Sciences, 49: 168-182.

Yeap BB. 2009. Are declining testosterone levels a major risk factor for ill-health in aging men? International Journal of Impotence Research, 21: 24-36.

Yeap BB. 2009. Testosterone and ill-health in aging men. Nature Clinical Practice Endocrinology and Metabolism, 5: 113121. 